\title{
ANALISIS TINGKAT OBJEKTIFITAS PENGISIAN EDOM UNTUK MENINGKATKAN KUALITAS PEMBELAJARAN DOSEN
}

\author{
Susi Erlinda ${ }^{1}$, M. Khairul Anam ${ }^{1 *}$, Torkis Nasution ${ }^{1}$, Ambiyar ${ }^{2}$, Dedy Irfan ${ }^{3}$, \\ ${ }^{1}$ Teknik Informatika, STMIK Amik Riau \\ ${ }^{2}$ Pendidikan Teknik Mesin, Universitas Negeri Padang \\ ${ }^{3}$ Pendidikan Teknik Elektronika, Universitas Negeri Padang \\ email: "khairulanam@sar.ac.id,
}

\begin{abstract}
Student objectivity in filling out E-EDOM is very necessary, the results of data analysis become the basis for the leadership in making decisions for learning strategies. Previous research has proven that the E-EDOM filling done by students is not objective. Efforts should be made so that students can fill it in seriously. This study aims to determine strategies that can be applied so that students can fill out the E-EDOM very objectively. Starting with analyzing and collecting data through a questionnaire. The Delon and Mclean model is used as a basis for creating questions in the questionnaire and processing the questionnaire data. The data collection technique used a simple random sampling method, with a population of 121 students from Amik Riau STMIK who were active in the 2019-2020 school year. Before processing, the data is tested for validity and reliability. After testing the validity and reliability, then testing the hypothesis to determine the relationship between variables in the Delon and Mc Lean success model. The results showed that each variable showed the effect of a positive relationship that was fully accepted with a value of 0.000 . This means that all the variables used in this study are related to one another. Even so, it is necessary to implement several strategies that must be done in an effort to fill out E-EDOM which is very objective by students.
\end{abstract}

Keywords: e-edom, delon and mclean models, objectivity, students.

\begin{abstract}
Abstrak: Objektifitas mahasiswa dalam mengisi E-EDOM sangat diperlukan, karena hasilnya akan dijadikan dasar oleh pimpinan dalam mengambil keputusan untuk masalah pembelajaran. Berdasarkan penelitian sebelumnya pengisian E-EDOM yang dilakukan mahasiswa masih banyak yang belum mengisinya dengan sangat objektif. Perlu dilakukan upaya agar mahasiswa dapat mengisinya dengan sunggun-sungguh. Penelitian ini bertujuan untuk menentukan strategi yang dapat diterapkan supaya mahasiswa dapat mengisi E-EDOM dengan sangat objektif. Diawali dengan melakukan analisa dan pengumpulan data melalui kuisioner. Model Delon and Mclean digunakan sebagai dasar untuk membuat pertanyaan dalam kuisioner dan melakukan pengolahan data kuesioner tersebut. Teknik pengumpulan data menggunakan metoda sampling simple random, dengan populasi mahasiswa STMIK Amik Riau yang aktif pada tahun ajaran 2019-2020 sejumlah 121 orang mahasiswa. Sebelum dilakukan pengolahan, terlebih dahulu data-data tersebut dilakukan uji validitas dan reability. Setelah dilakukan uji validitas dan reability, selanjutnya melakukan uji hipotesis untuk mengetahui hubungan antar variable yang ada pada model Delon and Mc Lean success. Hasil penelitian ini menunjukkan bahwa setiap variable menunjukkan pengaruh hubungan positif dapat diterima seluruhnya dengan nilai 0.000 . Artinya semua variable yang digunakan pada penelitian ini memiliki keterkaitan antara satu dengan lainnya. Walaupun demikian perlu diterapkan beberapa strategi yang harus dilakukan dalam upaya pengisian E-EDOM yang sangat objektif oleh mahasiswa.
\end{abstract}

Kata kunci: e-edom, delon and mclean model, mahasiswa, objektifitas. 


\section{PENDAHULUAN}

STMIK Amik Riau telah memiliki 3 Program Studi (Prodi), yaitu Teknik Informatika, Sistem Informasi dan Teknologi Informasi. Berbagai upaya dilakukan untuk menjamin kualitas pembelajaran di tiap prodi ini. Salah satu diantara adalah dengan melakukan evaluasi terhadap dosen oleh mahasiswa melalui sistem Elektronik Evaluasi Dosen Oleh Mahasiswa (E-EDOM). Aspek yang dinilai pada EDOM adalah sebanyak 6 aspek yang terdiri dari 26 pertanyaan.

Data E-EDOM yang telah terkumpul adalah sebanyak 20 periode semester. Setelah dicermati komentar mahasiswa tiap akhir semester pada EEDOM tersebut, di temukan kemiripan antar satu periode dengan periode selanjutnya dari mahasiswa yang sama pada dosen yang berbeda. Kondisi ini juga terjadi pada mahasiswa yang lainnya sebanyak 70\%. Pengisian E-EDOM dilakukan sebelum pelaksanaan Ujian Akhir Semester, dan dijadikan salah satu syarat untuk pengambilan Kartu Rencana Studi (KRS). Mahasiswa memandang bahwa pengisian E-EDOM masih sebagai persyaratan administratif. Sebaiknya harus menjadi sebuah kebutuhan sebagai upaya mencapai perbaikan secara berkelanjutan dalam meningkatkan kualitas proses pembelajaran. Berdasarkan komentar dari mahasiswa pada E-EDOM, tentang peningkatan proses pembelajaran ditemukan komentar reltive sama dari satu periode ke periode selanjutnya. Hal ini menunjukkan bahwa tidak terjadi perubahan ke arah yang lebih baik dari persepsi mahasiswa. Kualitas pembelajaran dosen perlu ditingkatkan dalam upaya meningkatkan kualitas mahasiswa dan lulusan. Kualitas pembelajaran degan keterampila belajar mahasiswa terdapat hubungan yang significan. Berdasarkan gambar tabel Anova diketahui nilai $\mathrm{Sig}=0,029<0,05$. Apabila nilai $\mathrm{Sig}<$ dari $\alpha(0,05)$ maka $\mathrm{H}_{0}$ ditolak. Artinya, variabel keterampilan mengajar dipengaruhi oleh kualitas pembelajaran [1].

Aspek yang mempengaruhi objektifitas pengisian E-EDOM adanya kedekatan antara mahasiswa dan dosen sebesar $60 \%$. Seorang dosen dituntut untuk bersikap ramah terhadap mahasiswa, aspek ini mempengaruhi tingkat objektifitas pengisisan E-EDOM sebesar 86,70\%. Sementara aspek kemampuan dosen $(40 \%)$, tegas $(33,3 \%)$, dan memiliki banyak pengalaman $(0 \%)$, tidak menjadi pertimbangan bagi mahasiswa dalam memberikan nilai positif terhadap seorang dosen [1]. Perlu dilakukan pengukuran untuk mengetahui tingkat objektifitas mahasiswa dalam mengisi E-EDOM. Beberapa model yang bisa digunakan untuk mengukur tingkat objektifitas antara lain; TAM, UTAUT dan Delon McLean. Dalam penelitian ini pengukuran tingkat objektifitas yang sesuai adalah Model Delon dan Mc. Lean. Model Delon akan melihat keterkaitan 6 variabel untuk mendapatkan hubungan antar variabel. Variabel itu antara lain: System Quality, Information Quality, Services Quality, Uses, Uses Satisfaction, Net Bonafide.

Delon and Mclean Model sudah banyak digunakan untuk mengukur kepuasaan terhadap sebuah sistem. Penelitian yang dilakukan oleh [2] melakukan studi dimensi pengetahuan dan kualitas sistem. Hasil dari penelitian ini diketahui bahwa pengetahuan faktual, konseptual, prosedural, metakognitif berpengaruh terhadap kualitas sistem. Hasil temuan kualitas sistem turut mempegaruhi perceived usefulness.

Penelitian lain melakukan pengujian sistem untuk mengetahui keberhasilan sistem dengan menggunakan Delon and Mclean Model. Hasil dari 
penelitian yang dilakukan ditemukan faktor kegagalan dan kesuksesaan yang dialami dijadikan evaluasi untuk dijadikan perbaikan kedepannya agar implementasi E-Government dapat berjalan dengan baik dan sesuai dengan yang diinginkan [3][4]. Selanjutnya penelitian yang dilakukan oleh [5] ingin mengidentifikasi penggunaan sistem pada rumah sakit atau SIRS. Hasil pada penelitian ditemukan bahwa pada umumnya pengguna SIRS lebih banyak menggunakan fungsi registrasi dan administrasi dari pada fungsi klinis lainnya. Faktor utama yang sangat berperan penting dalam menunjang pelayanan kesehatan adalah faktor ketersediaan Teknologi Informasi (TI) dan keterlibatan orang Teknik Informatika (TIK) dalam penggunaan SIRS.

Pada penelitian ini akan dilakukan pengukuran terhadap sistem E-EDOM STMIK Amik Riau. Penelitian ini menggunakan Delon and Mclean Model karena model ini mampu untuk mengetahui kendala-kendala yang sering terjadi pada sistem. Delon and Mclean model memiliki vaiabel yang membantu dalam menentukan tingkat objektivitas pengisian E-EDOM. Variabel tersebut adalah kualitas sistem, kualitas informasi, dan kualitas layanan.

Berdasarkan penelitian sebelumnya yang dilakukan oleh [6] menemukan hasil bahwa masih terdapat mahasiswa yang mengisi edom untuk kepentingan registrasi saja sehingga dalam melakukan pengisian edom mereka lakukan dengan asal-asalan. Hal ini tentunnya menjadi temuan yang sangat penting karena fungsi dari E-EDOM sendiri ialah melakukan perbaikan pada sisi pengajaran. Jika dilakukan pengisian secara asal-asalan oleh mahasiswa, dikhawatirkan tidak ada peningkatan kualitas dosen dalam proses pembelaja- ran. Sehingga nantinya akan berdampak kualitas lulusan

\section{METODE}

Gambar 1 adalah tahapan pada penelitian yang dilakukan:

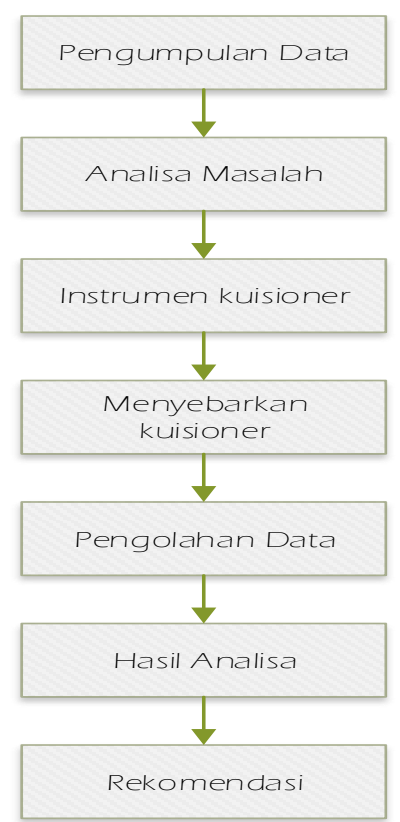

Gambar 1. Metodologi Penelitian

Dibawah ini merupakan penjelasan dari gambar 1 .

\section{Pengumpulan Data}

Proses pengumpulan data awal dilakukan dengan menganalisa data-data seperti persepsi mahasiswa, penelitian sebelumnya, dan hasil E-EDOM beberapa semester.

\section{Analisa Masalah}

Setelah data-data dikumpulkan selanjutnya adalah analisa masalah yang menjadi masalah dalam objektifitas pengisian E-EDOM. Kemudian dari masalah yang telah dianalisa berikutnya dilakukan penyebaran kuisioner untuk memperkuat hasil temuan. 


\section{Instrumen kuisioner}

Data yang diperoleh melalui analisa dilanjutkan dengan pembuatan kuisioner berdasarkan model Delon \& McLean success.

\section{Menyebarkan kuisioner}

Dalam penelitian ini, mahasiswa STMIK Amik Riau populasi, penetapan responden menggunakan simple random sampling. Dalam menentukan jumlah data sample menggunakan Rumus Slovin sesuai rumus (1):

$n=\frac{N}{1+N(e)^{2}}$

Keterangan:

$\mathrm{N}=$ besar populasi

$\mathrm{n}=$ besar sampel

$\mathrm{e}=$ persen kelonggaran ketidak ketelitian karena kesalahan pengambilan sampel yang masih dapat ditoleril atau diinginkan $(10 \%)$.

Dalam penelitian ini data populasi didasarkan mahasiswa aktif pada tahun akademis 2019-2020 berjumlah 798, dibulatkan menjadi 800 mahasiswa, sehingga dapat di tuliskan menjadi:

$n=\frac{800}{1+800(0.1)^{2}}=88.88$

Berdasarkan persamaan 1 responden pada penelitian ini berjumlah 88.88 orang atau 89 orang.

\section{Pengolahan Data}

Langkah selanjutnya adalah melakukan pengolahan data terhadap kuisioner yang telah diisi oleh mahasiswa berdasarkan Model Delon \& McLean Success. Sebelum dilakukan pengolahan, data-data tersebut dilakukan uji validitas dan reability. Setelah dilakukan uji validitas dan reability, selanjutnya melakukan uji hipotesis untuk menge- tahui hubungan antar variable yang ada pada model Delon and Mc Lean success.

\section{Hasil Analisa}

Hasil uji hipotesi yang telah diperoleh kemudian dilakukan analisa untuk membuat strategi yang akan digunakan STMIK Amik Riau dalam perbaikan system E-EDOM kedepannya. Hal ini dilakukan dalam upaya meningkatkan objektifitas mahasiswa dalam pengisian E-EDOM

\section{Kesimpulan}

Pengambilan kesimpulan terkait dengan hasil yang didapatkan pada penelitian ini.

\section{HASIL DAN PEMBAHASAN}

\section{Uji Validitas dan Reliability}

Data yang diperoleh dari penyebaran kuisioner, selanjutnya dilakukan pengolahan data. Sebelum melakukan pengolahan data, data tersebut dilakukan uji validitas dan Reliability untuk melihat data tersebut valid atau tidak untuk dilanjutkan ke pengolahan. Gambar 1 merupakan sebaran data yang akan diuji validitas dan reabilitasnya.

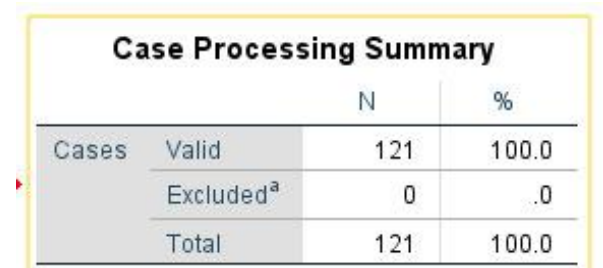

Gambar 2. Simpulan uji validitas sebaran data

Dari gambar 1 terlihat bahwa uji validitas yang dilakukan dengan menggunakan SPSS terhadap 121 data mahasiswa. Langkah selanjutnya yaitu melakukan pengujian validitas alat ukur 
DOI: https://doi.org/10.33330/jurteksi.v7i1.881

Available online at http://jurnal.stmikroyal.ac.id/index.php/jurteksi

dengan menggunakan rumus korelasi Product Moment [7]:

$r_{\text {hitung }}=\frac{n\left(\sum X Y\right)-\left(\sum X\right)\left(\sum Y\right)}{\sqrt{\left[n \cdot \sum X^{2}-\left(n \sum \sum X\right)^{2}\right)\left(n \cdot \sum Y^{2}-\left(\sum Y^{2}\right)\right]}}$

Keterangan:

n : Banyaknya Pasangan data X dan Y.

$\Sigma \mathrm{X} \quad$ : Total Jumlah dari Variabel X.

$\Sigma Y \quad$ : Total Jumlah dari Variabel Y.

$\Sigma \mathrm{X}^{2} \quad$ : Kuadrat dari Total Jumlal Variabel $\mathrm{X}$.

$\Sigma Y^{2} \quad$ : Kuadrat dari Total Jumlah Variabel Y.

$\Sigma X Y$ : Hasil Perkalian dari Total Jumlah Variabel X dan Variabel Y.

Lalu, setiap item pertanyaan di uji ke dalam rumus r-hitung dengan kriteria apabila r-hitung > r-tabel, maka dinyatakan valid dan jika sebaliknya maka tidak valid. penelitian ini mendapatkan 121 responden.

DISTRIBUSI NILAI $\mathbf{r}_{\text {tabel }}$ SIGNIFIKANSI $5 \%$ dan $1 \%$

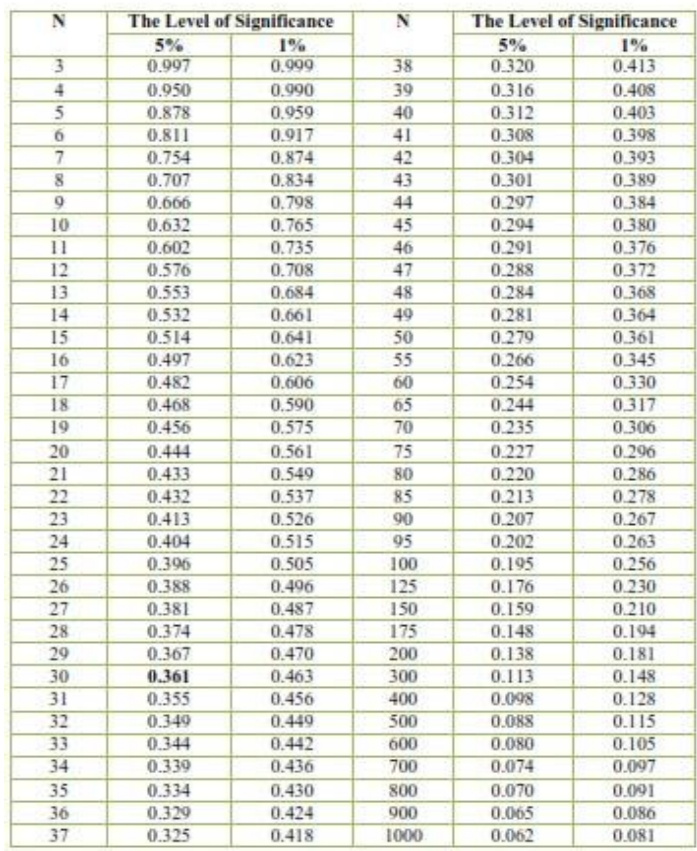

Gambar 3. Distribusi Nilai r-tabel [8]

hasil uji validitas bisa dilihat pada gambar 4.3, yang menjelaskan hasil uji validitas terhadap 23 butir pertanyaan

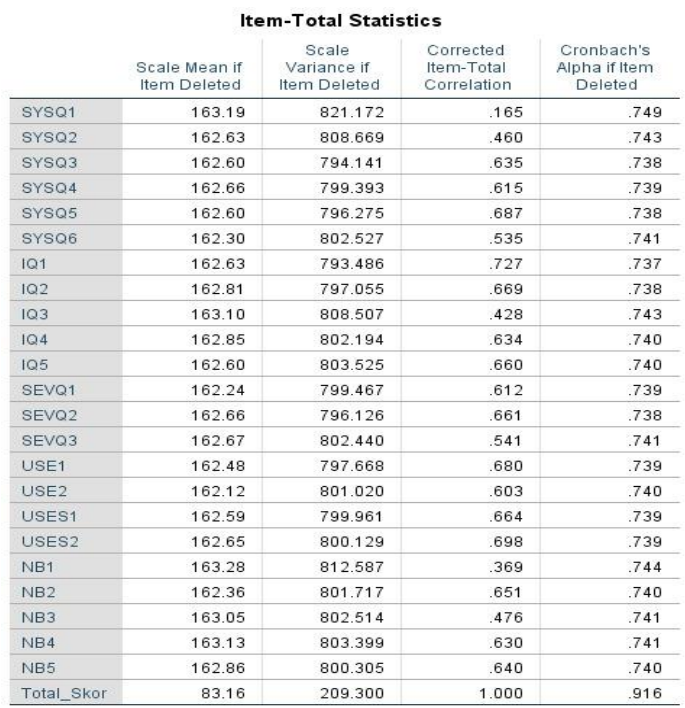

Gambar 4. Hasil uji validitas

Pengujian Instruman dikatakan relibialitas apabila instrumen dapat dilakukan pada waktu yang berbeda dengan hasil yang sama, pengujian reabilitas ini menggunakan metode alpha.

Penelitian ini akan menganalisa koefisien dari korelasinya. Pengukuran koefisien korelasi digunakan untuk menenukan tingkat signifikan atau tidak, dilakukan dengan nilai (Tabel $r$ Product Moment) untuk 5\% dengan derajat ke bebasan $(\mathrm{dk}=\mathrm{n}-1)$. Selanjutnya, mebuat keputusan dengan membandingkan $r-$ hitung dengan r-tabel. Adapun aturan keputusan: Jika r-hitung > r-tabel berarti reliabel, sebaliknya Jika r-hitung $<$ r-tabel berarti tidak reliabel.

Tabel 4. 1. Daftar Interpestasi Koefisien $r$

\begin{tabular}{ll}
\hline Interval koefisien & Tingkat hubungan \\
\hline $0.800-1.000$ & Sangat Tinggi \\
\hline $0.600-0.800$ & Kuat \\
\hline $0.400-0.600$ & Cukup \\
\hline $0.200-0.400$ & Rendah \\
\hline $0.000-0.200$ & Sangat Rendah
\end{tabular}

Sumber: [9]

Perhitungan yang dilakukan menggunakan spss 16 diperoleh hasil reliabilitas dari kuesioner atau instrumen 
adalah 0.750 yang apabila di interprestasikan kepada koefisien $\mathrm{r}$ maka instrument tersebut memiliki reliabilitas yang sangat tinggi.

\begin{tabular}{|c|c|}
\hline \multicolumn{2}{|c|}{ Reliability Statistics } \\
\hline $\begin{array}{l}\text { Cronbach's } \\
\text { Alpha }\end{array}$ & $\mathrm{N}$ of Items \\
\hline .750 & 24 \\
\hline
\end{tabular}

Gambar 1.Hasil Reliability

\section{Uji Hipotesis}

Berdasarkan uji menggunakan Kendall's tau_b dan Spearman's rho dimana bila nilai Signifikansi (Sig.) $<0,05$ maka brepengaruh terhadap variabel terikat atau hipotesis $\mathrm{H}_{0}$ diterima, sebaliknya jika nilai Signifikansi (Sig.) > 0,05 maka tidak ada pengaruh terhadap variabel terikat atau hipotesis ditolak [10]. Berikut ini adalah uji hipotesis yang dilakukan:

Uji hipotesis yang dilakukan antara variable kuliatas informasi dengan variable penggunaan sistem. Hipotesis 1a (H1a). Kualitas informasi (information quality) berpengaruh positif dan signifikan terhadap pengguna sistem (user).

\begin{tabular}{|c|c|c|c|c|}
\hline & & & USE_mean & IQ_mean \\
\hline \multirow[t]{6}{*}{ Kendall's tau_b } & \multirow[t]{3}{*}{ USE_mean } & Correlation Coefficient & 1.000 & $288^{* \prime}$ \\
\hline & & Sig. (2-tailed) & & .000 \\
\hline & & $\mathrm{N}$ & 121 & 121 \\
\hline & \multirow[t]{3}{*}{ IQ_mean } & Correlation Coefficient & $.288^{*}$ & 1.000 \\
\hline & & Sig. (2-tailed) & .000 & \\
\hline & & $\mathrm{N}$ & 121 & 121 \\
\hline \multirow[t]{6}{*}{ Spearman's rho } & \multirow[t]{3}{*}{ USE_mean } & Correlation Coefficient & 1.000 & $.361^{*}$ \\
\hline & & Sig. (2-tailed) & . & .000 \\
\hline & & $\mathrm{N}$ & 121 & 121 \\
\hline & \multirow[t]{3}{*}{ IQ_mean } & Correlation Coefficient & $.361^{\prime \prime}$ & 1.000 \\
\hline & & Sig. (2-tailed) & .000 & \\
\hline & & $\mathrm{N}$ & 121 & 121 \\
\hline
\end{tabular}

Gambar 5. Korelasi antara Kualitas Informasi dengan pengguna sistem

Gambar 5 menunjukkan bahwa dengan menggunakan pengujian korelasi Kendal dan Spearman's rho memiliki nilai signifikansi korelasi positif sebesar 0,288 dan 0,361 , serta nilai signifikansi hipotesa (2-tailed) $<0,05$ yang berarti hipotesa diterima, sehingga dapat disimpulkan bahwa variable penggunaan sistem memiliki hubungan keterkaitan dengan variable kualitas informasi.

Uji hipotesis yang dilakukan antara variable kualitas informasi dengan variable kepuasan pengguna. Hipotesis $1 b$ (H1b). Kualitas informasi (information quality) berpengaruh positif dan signifikan terhadap kepuasan pengguna (user satisfaction).

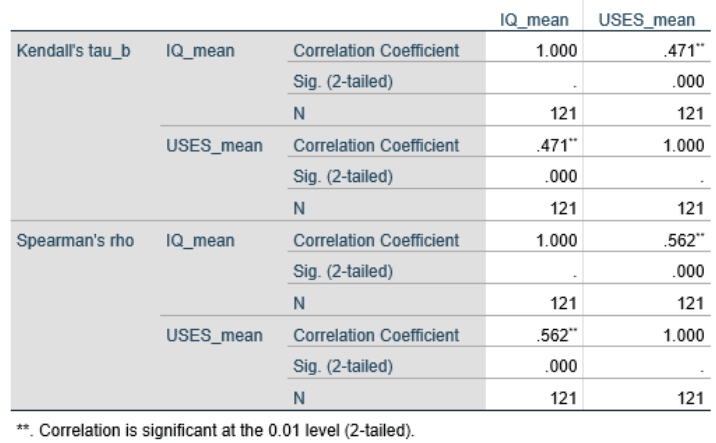

Gambar 6. Korelasi antara Kualitas In-

formasi dengan Kepuasan Pengguna

Gambar 6 menunjukkan bahwa dengan menggunakan pengujian korelasi Kendal dan Spearman's rho memiliki nilai signifikansi korelasi positif sebesar 0,471 dan 0,562 serta nilai signifikansi hipotesa (2-tailed) $<0,05$ yang berarti hipotesa diterima, sehingga dapat disimpulkan bahwa variable Kualitas Informasi memiliki hubungan keterkaitan dengan variable Kepuasan Pengguna.

Uji hipotesis yang dilakukan antara variable kualitas sistem dengan kepuasan pengguna.

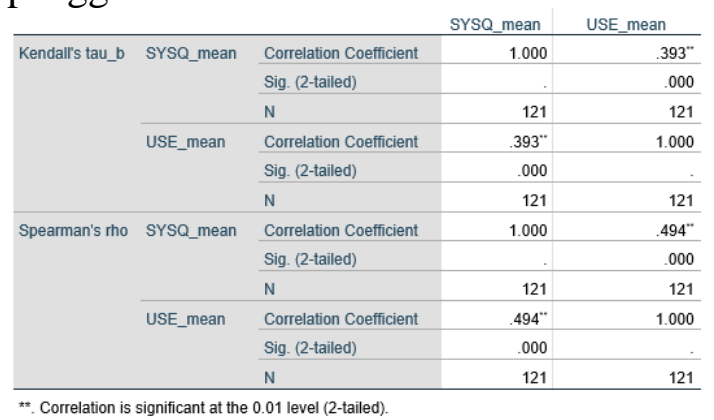


Gamabr 7. Korelasi antara Kualitas Sistem dengan Kepuasan Pengguna

Gambar 7 menunjukkan bahwa dengan menggunakan pengujian korelasi Kendal dan Spearman's rho memiliki nilai signifikansi korelasi positif sebesar 0,393 dan 0,494 serta nilai signifikansi hipotesa (2-tailed) $<0,05$ yang berarti hipotesa diterima, sehingga dapat disimpulkan bahwa variable Kualitas Sistem memiliki hubungan keterkaitan dengan variable Kepuasan Pengguna.

Uji Hipoteses yang dilakukan antara Kualitas sistem (system quality) berpengaruh positif dan signifikan terhadap kepuasan pengguna (user satisfaction).

\begin{tabular}{|c|c|c|c|c|}
\hline & & & SYSQ_mean & USES_mean \\
\hline \multirow[t]{6}{*}{ Kendall's tau_b } & SYSQ_mean & Correlation Coefficient & 1.000 & $.424^{\prime \prime}$ \\
\hline & & Sig. (2-tailed) & & .000 \\
\hline & & $\mathrm{N}$ & 121 & 121 \\
\hline & USES_mean & Correlation Coefficient & $.424^{\prime \prime}$ & 1.000 \\
\hline & & Sig. (2-tailed) & .000 & \\
\hline & & $\mathrm{N}$ & 121 & 121 \\
\hline \multirow[t]{6}{*}{ Spearman's tho } & SYSQ_mean & Correlation Coefficient & 1.000 & .522 \\
\hline & & Sig. (2-tailed) & & .000 \\
\hline & & $\mathrm{N}$ & 121 & 121 \\
\hline & USES_mean & Correlation Coefficient & $.522 "$ & 1.000 \\
\hline & & Sig. (2-tailed) & .000 & \\
\hline & & $N$ & 121 & 121 \\
\hline
\end{tabular}

Gambar 8. kualitas sistem dengan kepuasan pengguna

Uji Hipotesis antara Kualitas pelayanan (service quality) akan berpengaruh positif dan signifikan terhadap penggunaan sistem (use).

\begin{tabular}{|c|c|c|c|c|}
\hline & & & SEVQ_mean & USE_mean \\
\hline \multirow[t]{6}{*}{ Kendall's tau_b } & \multirow[t]{3}{*}{ SEVQ_mean } & Correlation Coefficient & 1.000 & $.336^{*}$ \\
\hline & & Sig. (2-tailed) & & .000 \\
\hline & & $\mathrm{N}$ & 121 & 121 \\
\hline & \multirow[t]{3}{*}{ USE_mean } & Correlation Coefficient & $.336^{\prime \prime}$ & 1.000 \\
\hline & & Sig. (2-tailed) & .000 & \\
\hline & & $\mathrm{N}$ & 121 & 121 \\
\hline \multirow[t]{6}{*}{ Spearman's rho } & \multirow[t]{3}{*}{ SEVQ_mean } & Correlation Coefficient & 1.000 & $.419^{\prime \prime}$ \\
\hline & & Sig. (2-tailed) & & .000 \\
\hline & & $\mathrm{N}$ & 121 & 121 \\
\hline & \multirow[t]{3}{*}{ USE_mean } & Correlation Coefficient & $.419^{*}$ & 1.000 \\
\hline & & Sig. (2-tailed) & .000 & \\
\hline & & $\mathrm{N}$ & 121 & 121 \\
\hline
\end{tabular}

Gambar 9. variable Kualitas Pelayanan dengan variable Penggunaan Sistem

Dari gambar 9 dapat dilihat bahwa dengan menggunakan pengujian korelasi Kendal dan Spearman's rho memiliki nilai signifikansi korelasi positif sebesar 0,336 dan 0,419 serta nilai signifikansi hipotesa (2-tailed) $<0,05$ yang berarti hipotesa diterima, sehingga dapat disimpulkan bahwa variable Kualitas Pelayanan memiliki hubungan keterkaitan dengan variable Penggunaan Sistem.

Kualitas pelayanan (service quality) akan berpengaruh positif dan signifikan terhadap kepuasan pengguna (user satisfaction).

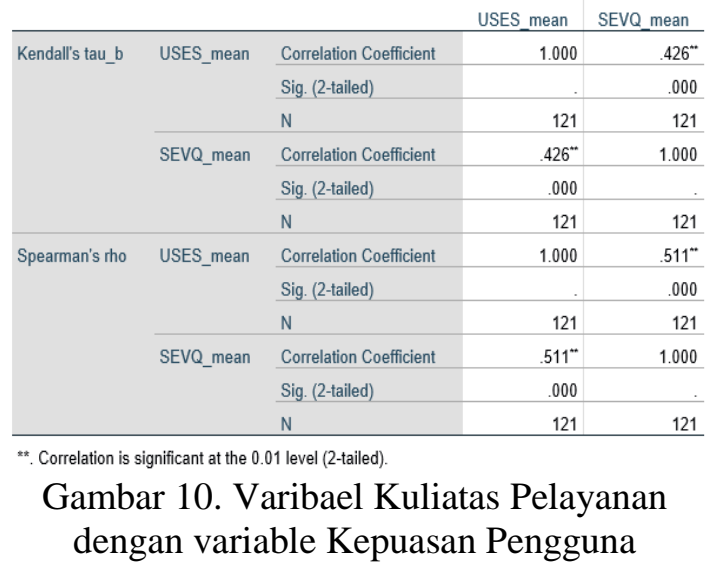

Dari Gambar 10 dapat dilihat bahwa dengan menggunakan pengujian korelasi Kendal dan Spearman's rho memiliki nilai signifikansi korelasi positif sebesar 0,426 dan 0,511 serta nilai signifikansi hipotesa (2-tailed) $<0,05$ yang berarti hipotesa diterima, sehingga dapat disimpulkan bahwa variable Kualitas Pelayanan memiliki hubungan keterkaitan dengan variable Kepuasan Pengguna.

Penggunaan sistem (use) akan berpengaruh positif dan signifikan terhadap kepuasan pengguna (user satisfaction)

\begin{tabular}{|c|c|c|c|c|}
\hline & & & USE mean & USES mean \\
\hline \multirow[t]{6}{*}{ Kendall's tau_b } & USE_mean & Correlation Coefficient & 1.000 & $.494^{\prime \prime}$ \\
\hline & & Sig. (2-tailed) & & .000 \\
\hline & & $\mathrm{N}$ & 121 & 121 \\
\hline & USES_mean & Correlation Coefficient & $.494^{-1}$ & 1.000 \\
\hline & & Sig. (2-tailed) & .000 & \\
\hline & & $\mathrm{N}$ & 121 & 121 \\
\hline \multirow[t]{6}{*}{ Spearman's rho } & USE_mean & Correlation Coefficient & 1.000 & .565 \\
\hline & & Sig. (2-tailed) & & .000 \\
\hline & & $\mathrm{N}$ & 121 & 121 \\
\hline & USES_mean & Correlation Coefficient & $.565^{\circ}$ & 1.000 \\
\hline & & Sig. (2-tailed) & .000 & \\
\hline & & $\mathrm{N}$ & 121 & 121 \\
\hline
\end{tabular}


Gambar 11. Hipotesis variable Pengguna Sistem dengan Kepuasan Pengguna

Dari Gambar 11 dapat dilihat bahwa dengan menggunakan pengujian korelasi Kendal dan Spearman's rho memiliki nilai signifikansi korelasi positif sebesar 0,494 dan 0,565 serta nilai signifikansi hipotesa (2-tailed) <0,05 yang berarti hipotesa diterima, sehingga dapat disimpulkan bahwa variable Penggunaan Sistem memiliki hubungan keterkaitan dengan variable Kepuasan Pengguna.

Hipotasa Penggunaan Sistem (use) akan berpengaruh positif dan signifikan terhadap Manfaat Bersih yang didapatkan (net benefit).

\begin{tabular}{|c|c|c|c|c|}
\hline & & & USE mean & NB_mean \\
\hline \multirow[t]{6}{*}{ Kendall's tau_b } & \multirow[t]{3}{*}{ USE_mean } & Correlation Coefficient & 1.000 & $.355^{\prime \prime}$ \\
\hline & & Sig. (2-tailed) & & .000 \\
\hline & & $\mathrm{N}$ & 121 & 121 \\
\hline & \multirow[t]{3}{*}{ NB_mean } & Correlation Coefficient & $.355^{\circ}$ & 1.000 \\
\hline & & Sig. (2-tailed) & .000 & \\
\hline & & $\mathrm{N}$ & 121 & 121 \\
\hline \multirow[t]{6}{*}{ Spearman's rho } & \multirow[t]{3}{*}{ USE_mean } & Correlation Coefficient & 1.000 & $.444^{\prime \prime}$ \\
\hline & & Sig. (2-tailed) & & .000 \\
\hline & & $\mathrm{N}$ & 121 & 121 \\
\hline & \multirow[t]{3}{*}{ NB_mean } & Correlation Coefficient & $.444^{\prime \prime}$ & 1.000 \\
\hline & & Sig. (2-tailed) & .000 & \\
\hline & & $\mathrm{N}$ & 121 & 121 \\
\hline
\end{tabular}

Gambar 12. Hipotesis antara variable

Penggunaan Sistem dengan variable Manfaat Bersih

Dari gambar 12 dapat dilihat bahwa dengan menggunakan pengujian korelasi Kendal dan Spearman's rho memiliki nilai signifikansi korelasi positif sebesar 0,355 dan 0,44 , serta nilai signifikansi hipotesa (2-tailed) $<0,05$ yang berarti hipotesa diterima, sehingga dapat disimpulkan bahwa variable Penggunaan Sistem memiliki hubungan keterkaitan dengan variable Manfaat Bersih.

Uji Hipotesis Kepuasan pengguna (user satisfaction) akan berpengaruh positif dan signifikan terhadap manfaat bersih yang didapatkan (net benefit).

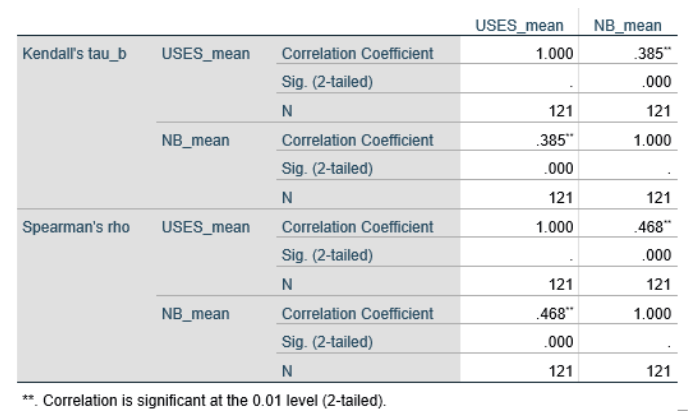

Gambar 12. Uji Hipotesis Kepuasan

Pengguna dengan Manfaat Bersih

Dari Gambar 12 dapat dilihat bahwa dengan menggunakan pengujian korelasi Kendal dan Spearman's rho memiliki nilai signifikansi korelasi positif sebesar 0,385 dan 0,468, serta nilai signifikansi hipotesa (2-tailed) $<0,05$ yang berarti hipotesa diterima, sehingga dapat disimpulkan bahwa variable kepuasan pengguna memiliki hubungan keterkaitan dengan variable Manfaat Bersih.

\section{Strategi Peningkatan Objektifitas}

Dari uji hipotesis yang telah dilakukan, hasil yang didapat menunjukkan bahwa semua variable diterima. Artinya indikasi yang disebutkan pada latar belakang tidak seluruhnya terbukti. Berdasarkan hasil pengolahan data kuisioner yang telah disebarkan ke mahasiswa khusus untuk tingkat objektifitas pengisian E-EDOM, didapatkan hasil sebagai berikut :

Tabel 10. Tingkat Objektiftas Pengisian E-EDOM oleh Mahasiswa

Tingkat Objek- Jumlah Persentase tif

\begin{tabular}{lll}
\hline Sangat Objektif & $25 / 118 * 100 \%$ & $\mathbf{2 1 \%}$ \\
\hline Objektif & $51 / 118^{*} 100 \%$ & $\mathbf{4 3 \%}$ \\
\hline Sedang & $31 / 118^{*} 100 \%$ & $\mathbf{2 6 \%}$ \\
\hline Tidak Objektif & $7 / 118^{*} 100 \%$ & $\mathbf{5 \%}$ \\
\hline $\begin{array}{l}\text { Sangat tidak } \\
\text { objektif }\end{array}$ & $4 / 118 * 100 \%$ & $\mathbf{3 \%}$ \\
\hline Total & $\mathbf{1 0 0 \%}$ \\
\hline Rata-rata & $\mathbf{2 3 . 6 \%}$ \\
\hline
\end{tabular}


Berdasarkan data pada table diatas, dapat dilihat bahwa mahasiswa yang mengisi E-EDOM dengan Sangat Objektif baru $21 \%$, Objektif 43\%, Sedang $26 \%$, Tidak Objektif 5\% dan Sangat Tidak Objektif 3\%. Hasil penelitian ini, berbeda dengan penelitian yang pernah dilakukan sebelumnya (tahun 2016 oleh Dwi Megawati) yang yang mendapatkan hasil bahwa pengisian E-EDOM tidak objektif. Barangkali ini disebabkan karena sudah ada kesadaran dari mahasiswa tentang pentingnya E-EDOM ini untuk perbaikan kualitas proses pembelajaran.

Dari data yang didapat, pimpinan menginginkan persentase jumlah mahasiswa yang mengisi E-EDOM dengan Sangat Objektif perlu ditingkatkan lagi untuk mendapatkan data yang lebih akurat lagi. Untuk perlu adanya strategi yang dilakukan berdasarkan hasil penelitian dan saran yang diberikan mahasiswa terhadap system E-EDOM, diantaranya;

1. Sosialisasi E-EDOM, meyakinkan kepada mahasiswa pentingnya mengisi E-EDOM untuk peningkatan mutu pembelajaran.

2. Meninjau ulang jumlah pertanyaan dan isi pertanyaan yang ada pada EEDOM. Salah satu penyebab mahasiswa mengisi asalan adalah karena jumlah pertanyaan yang terlalu banyak.

3. Diberi kesempatan kepada mahasiswa untuk mengisi E-EDOM setiap saat.

4. Waktu pengisian E-EDOM. Sebelumnya pengisian E-EDOM dilakukan sebelum pelaksanaan Ujian Akhir Semester dan dijadikan sebagai syarat untuk pengambilan Kartu Ujian, hal ini membuat mahasiswa terburu-buru dan dosen tidak memiliki waktu untuk melakukan perbaikan proses pembelajaran pada kelas yang diajar dosen pada semester itu. Maka untuk selanjut- nya pengisian E-EDOM dilakukan sebelum pelaksanaan Ujian Tengah Semester (UTS). Dosen akan menjadikan sebagai syarat untuk pelaksanaan UTS.

5. Pemberian reward dan punishment terhadap dosen berdasarkan hasil EEDOM. Dosen yang memiliki nilai 5 tertinggi akan diberikan reward berupa sertifikat. Dosen yang memiliki nilai E-EDOM kurang dari 3, harus mengisi surat perjanjian untuk melakukan perubahan metode pembelajaran sesuai dengan saran yang membangun dari mahasiswa. Mahasiswa berhak mengetahui reward dan punisment ini.

6. Membuat pemgumuman pekan pengisian E-EDOM, melalui Banner yang dipasang di beberapa tempat, guna menimbulkan semangat mahasiswa untuk mengisinya.

7. E-EDOM dijadikan sebagai dasar pimpinan untuk membuat kebijakan dalam proses pembelajaran.

8. Tampilan E-EDOM dibuat lebih menarik

9. Sosialisasi panduan pengisian EEDOM, Karena terjadinya kontradiksi antara komentar mahasiswa dengan nilai yang mereka isikan di E-EDOM

\section{SIMPULAN}

Dari uji hipotesis yang telah dilakukan, hasil yang didapat menunjukkan bahwa semua variable diterima yaitu dengan nilai 0.00 dimana angka tersebut dibawah 0.05. Artinya indikasi yang disebutkan pada latar belakang tidak terbukti. Tetapi pada komentar yang diberikan mahasiswa melalui kuisioner menunjukkan adanya permasalahan pada sistem. Oleh karena itu penelitian ini menemukan strategi-strategi agar mahasiswa mengisi E- EDOM dengan objektif. 


\section{DAFTAR PUSTAKA}

[1] A. Fitriana, "Pengaruh Kualitas Pembelajaran Dosen Terhadap Keterampilan Mengajar Mahasiswa," Ensains J., vol. 1, no. 2, pp. 112-117, 2018.

[2] T. W. Sukiyaningsih, "Studi Dimensi Pengetahuan Dan Kualitas Sistem : Pendekatan D \& $M$ Is Success Model ( Studi Penggunaan e-SPT Orang Pribadi Pada KPP Kebon Jeruk Satu Jakarta Barat )," J. Ekon. Vokasi, vol. 3, no. 1, 2020.

[3] P. H. Saputro, D. Budiyanto, and J. Santoso, "Model Delone and Mclean Untuk Mengukur Kesuksesan E-Government Kota Pekalongan," Sci. J. Informatics, vol. 2, no. 1, pp. 1-8, 2016.

[4] J. M. Hudin and D. Riana, "Kajian Model Kesuksesan Sistem Informasi Delone \& Mclean Pada Pengguna Sistem Informasi Akuntansi Accurate Di Kota Sukabumi," J. Sist. Inf., vol. 12, no. 1, p. 1, 2016.

[5] F. R. Rumambi, S. Robo, and C. Amalia, "Identifikasi Dampak Penggunaan Sistem Informasi Rumah Sakit (SIRS) Terhadap Pelayanan Kesehatan Menggunakan Hot-Fit Model 2006," J. Media Inform. Budidarma, vol. 4, no. 1, p. 216, 2020.

[6] D. Megawati, "Analisis perbandingan persepsi penggunaan E-EDOM antara dosen dan mahasiswa," STMIK Amik Riau, 2016.

[7] I. Ernawati and T. Sukardiyono, "Uji Kelayakan Media Pembelajaran Interaktif Pada Mata Pelajaran Administrasi Server," Elinvo (Electronics, Informatics, Vocat. Educ., vol. 2, no. 2, p. 204, 2017.

[8] adminspssstatistik, "cara membaca dan mencari $r$ tabel product moment,"

http://www.spssstatistik.com/,

2016. [Online]. Available: http://www.spssstatistik.com/caramembaca-dan-mencari-r-tabelproduct-moment/. [Accessed: 07Jul-2020].

[9] C. V. Bertan, A. K. T. Dundu, and R. J. M. Mandagi, "Pengaruh Pendayagunaan Sumber Daya Manusia (Tenaga kerja) Terhadap Hasil Pekerjaan (Studi Kasus Perumahan Taman Mapanget Raya (Tamara)," Sipil Statik, vol. 4, no. 1, pp. 13-20, 2016.

[10] S. Raharjo, "Cara Melakukan Uji t Parsial dalam Analisis Regresi dengan SPSS," https://www.spssindonesia.com/, 2014. [Online]. Available: https://www.spssindonesia.com/20 14/02/cara-mudah-melakukan-ujit-dengan-spss.html. [Accessed: 17Aug-2020]. 